\title{
Tapping into local ecological knowledge to assess the former importance and current status of sawfishes in Mexico
}

\author{
Ramón Bonfil ${ }^{1, *}$, Melina Ricaño-Soriano ${ }^{1,2}$, Oscar Uriel Mendoza-Vargas ${ }^{1,3}$, \\ Iván Méndez-Loeza ${ }^{4}$, Juan Carlos Pérez-Jiménez ${ }^{4}$, Nataly Bolaño-Martínez ${ }^{1,5}$, \\ Paola Palacios-Barreto ${ }^{1,5,6}$
}

\author{
${ }^{1}$ Océanos Vivientes A. C., Cerrada Monserrat 9, La Candelaria, Coyoacan, Mexico City 04380, Mexico \\ ${ }^{2}$ Revolucion 9, Sector Pajaritos, Tihuatlán, Veracruz 92902, México \\ ${ }^{3}$ Posgrado en Ciencias Biológicas, Universidad Nacional Autónoma de México, Mexico City 04510, Mexico \\ ${ }^{4}$ El Colegio de la Frontera Sur, Unidad Campeche, Campeche, Campeche 24500, Mexico \\ ${ }^{5}$ Instituto de Ciencias del Mar y Limnología, Universidad Nacional Autónoma de México, Mexico City 04510, Mexico \\ ${ }^{6}$ SQUALUS, Fundación colombiana para la investigación y conservación de tiburones y rayas. Calle 10A No. 72-35, Cali, Colombia
}

\begin{abstract}
Information on the occurrence and abundance of the Critically Endangered smalltooth sawfish Pristis pectinata and largetooth sawfish P. pristis across most of their former range is needed for a comprehensive global conservation status assessment. The current presence of both species in Mexico and the rest of Latin America remains uncertain in the absence of dedicated studies. During 2015, we performed the first nationwide study of sawfishes in Mexico. We developed specific materials to survey fishers, raise community awareness, and publicize sawfish conservation needs. We interviewed 794 fishers in 71 localities along the Atlantic and Pacific coasts of Mexico. Additional data from a similar 2010-2011 survey of 39 fishers in Tabasco and Campeche were also included in the analysis. Both species might be nearly extirpated from Mexico. Interviewees reported modal decadal dates of last sighting as the 1980s for the smalltooth sawfish along the Atlantic coast and as the 1970s for the largetooth sawfish along both coasts. No confirmed reports of recent $(<5 \mathrm{yr})$ sightings were reported. However, a live juvenile smalltooth sawfish was caught in Veracruz in January 2016. Historical importance maps were reconstructed, indicating that both species were distributed along the entire surveyed area; the smalltooth sawfish was especially common in Campeche, Quintana Roo, and Tabasco, while the largetooth sawfish was common in Campeche, Colima, and Chiapas. Both species must be re-categorized in Mexican legislation for species at risk of extinction from 'threatened' to 'endangered'.
\end{abstract}

KEY WORDS: Pristis pectinata Pristis pristis $\cdot$ Pristidae $\cdot$ Historical importance $\cdot$ Fisheries · Ecology $\cdot$ Conservation

\section{INTRODUCTION}

Recovery and conservation of endangered species requires, among other things, accurate and updated information about their geographic distribution and abundance. Sawfishes (Pristidae) are considered the most threatened marine fish group in the world (Dulvy et al. 2016), but adequate assessment of their

*Corresponding author: ramon.bonfil@oceanosvivientes.org conservation status in most of their former rangeespecially among developing nations - is hampered by lack of baseline information (Harrison \& Dulvy 2014).

Two sawfishes are known from Mexico, the smalltooth sawfish Pristis pectinata and the largetooth sawfish P. pristis (Castro-Aguirre \& Espinosa Pérez 1996). However, available information is restricted to

(C) The authors 2018. Open Access under Creative Commons by Attribution Licence. Use, distribution and reproduction are unrestricted. Authors and original publication must be credited. 
records of occurrence in taxonomic checklists, and fish catalogues (Herrera 1896, Castro-Aguirre \& Espinosa Pérez 1996, Schmitter-Soto et al. 2009, Guzmán \& Meráz-Munguía 2013) or references to their former exploitation in fishery reports (Carranza 1959); not a single scientific study focused on sawfishes had ever been carried out in Mexico until recently when Bonfil et al. (2017) used old photographs and trophy rostra to reconstruct the former distribution of both species in Mexico, and demonstrated the role of fisheries in their precipitous decline.

Local ecological knowledge (LEK), also known as fishers' local ecological knowledge, has been used to uncover baseline information about poorly documented or threatened species, including teleosts, sea turtles, cetaceans, and sawfish (e.g. Tregenza 1992, Seitz \& Poulakis 2002, Carreras et al. 2004, Turvey et al. 2010). In addition, the last decade has seen a growing number of studies applying LEK to recover information about sawfishes in Africa, Asia, and South America (e.g. Robillard \& Séret 2006, Giglio et al. 2015, Hossain et al. 2015). This paper presents results from a LEK approach as part of the first study on the conservation status of both sawfishes in Mexico. Previous results from this long-term project only reported information about historical photographs and trophy rostra (Bonfil et al. 2017). Here, we provide further proof of the decline of sawfishes in Mexico using new lines of evidence, together with data on their ecology, the former and current occurrence and distribution of both species, historical information about their capture in fisheries, use, and importance to coastal communities.

\section{MATERIALS AND METHODS}

\section{Background research}

First, we gathered historical records of sawfishes in Mexico from the scientific and vernacular literature (e.g. newspapers). This provided an initial glimpse of the former sawfish distribution and helped plan the geographical coverage of our research. Next, we compiled a collection of records of old photographs and trophy rostra during the surveys described in the following section. Analysis of the photograph and rostrum information showed that both sawfish species were widely distributed in Mexico, but are currently rare or possibly extirpated (Bonfil et al. 2017).

\section{Surveys and data gathering}

Between August and November 2015, we (R.B., M.R.-S., O.U.M.-V., N.B.-M., and P.P.-B.) traveled over $10800 \mathrm{~km}$ covering the entire former range of sawfishes in Mexico, from Matamoros, Tamaulipas

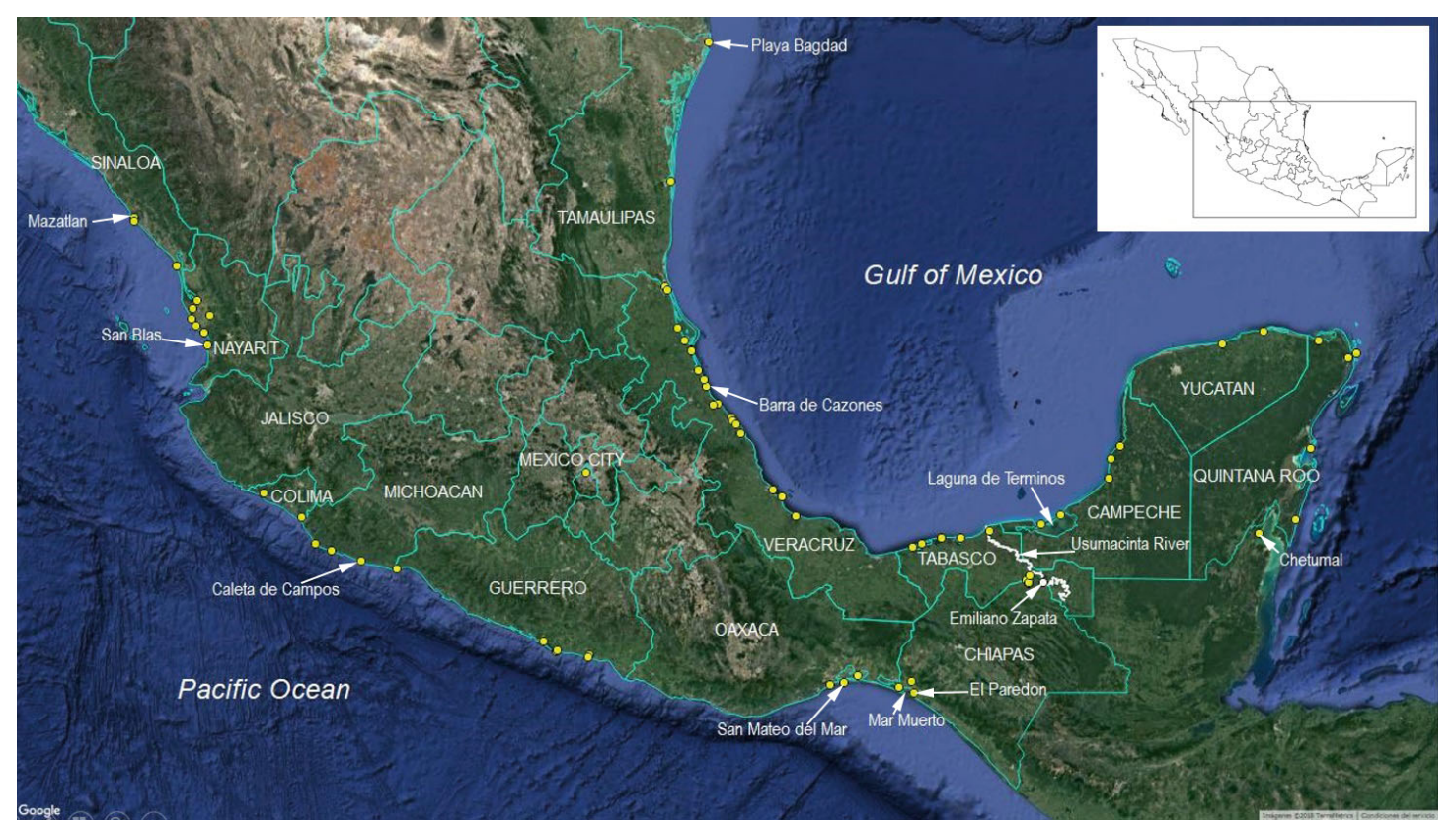

Fig. 1. Map showing the 71 locations visited during the 2015 national survey (yellow dots). These include all coastal states where sawfishes have been reported (Castro-Aguirre \& Espinosa Pérez 1996) except Jalisco, which could not be surveyed due to Hurricane Patricia, which made landfall there on 23 October 2015 
(western Gulf of Mexico), to Chetumal, Quintana Roo (Caribbean), and from Mazatlán, Sinaloa (southeastern Gulf of California), to El Paredón, Chiapas (southeastern Mexican Pacific). Visited localities are shown in Fig. 1. Some details of the methodology followed during these surveys have already been reported (Bonfil et al. 2017) and included a 32-question questionnaire to collect information about the past and current presence of sawfishes, their importance to local communities, local knowledge about sawfish life history, ecology, and conservation, as well as their cultural value (Supplementary Material in Bonfil et al. 2017). Questions included approximate date, gear, and locality of capture of as many specimens as interviewees could remember, whether they could identify the 2 species occurring in Mexico, local names given to each, whether they thought sawfishes still existed in the area, the importance of sawfishes to them and how they were used, as well as their knowledge about habitat preferences, seasonality, pupping season, nursery grounds, feeding habits, rostrum function, whether they were considered dangerous, and folklore.

Species identification was aided by presenting interviewees with a photograph and a scientific drawing of complete specimens of each species, and photographs of their rostra. Identification was considered correct only when interviewees properly matched photographs of the complete specimen with the corresponding rostrum and said this was the species they knew.

We prepared a promotional poster that outlined the background and purpose of our project and requested reports of any sawfish information available (Fig. S1 in the Supplement at www.int-res. com/articles/suppl/n036p213_supp.pdf); nearly 1000 posters were posted along both Mexican coasts and along the Usumacinta River (southern Gulf of Mexico). Finally, we obtained additional information on sightings, old photographs, and rostra, via a FaceBook page designed to keep the public informed and involved (Facebook: Proyecto Pristis Mexico).

Additional data on presence in the southern Gulf of Mexico states of Tabasco and Campeche was gathered by 2 of us (I.M.-L. and J.C.P.-J.) between November 2010 and November 2011, using semistructured interviews (Fig. S2 in the Supplement). These included 3 interviewees in Tabasco and 36 in Campeche who had information about sawfishes. Information queried included when were sawfishes last caught or seen, capture locality and gear, numbers caught, and estimated total lengths.

\section{Data analysis}

Data were analyzed by coast (Gulf of Mexico and Caribbean [hereafter, Atlantic] and Pacific), state, and nationwide. The historical occurrence of both species was determined using the capture locations of sampled rostra and old photographs of specimens. Estimates of historic importance of sawfishes (historic average of sawfish encounters) of each species in each state was calculated from frequency distribution histograms of the approximate total number of sawfishes caught or seen in the lifetime of interviewees. The number of observations in each size class of these histograms was multiplied by the midpoint of each class, these values were added across classes and the total was divided by the total number of interviewees. We produced maps with contours of historic importance for each species by plotting the above data into color-coded groups. Information on sawfish habitat was split into juveniles $(<3 \mathrm{~m}$ estimated total length, ETL) and adults ( $\geq 3 \mathrm{~m}$ ETL) following Poulakis et al. (2011).

\section{RESULTS}

Our background literature research showed 26 historical records of sawfishes in Mexico. These covered most of the Atlantic coast, from Playa Bagdad, Tamaulipas, next to the border with the United States, to Chetumal in the south, next to the border with Belize (Fig. 1, Table S1 in the Supplement). Along the Pacific coast, records spanned from Mazatlán, Sinaloa, near the mouth of the Gulf of California, to Mar Muerto, in the southernmost state of Chiapas.

\section{Coverage of surveys}

A total of 805 people, mostly fishers, were interviewed in the 71 locations visited during the 2015 national survey (Fig. 1; 245 individuals who had firsthand information about sawfishes responded to our questionnaire (hereafter 'interviewees'; Fig. S3 in the Supplement). Of these, 168 questionnaires were answered along the Atlantic coast (from north to south: Tamaulipas, 32; Veracruz, 68; Tabasco, 29; Campeche, 8; Yucatan, 4; Quintana Roo, 27) and 77 along the Pacific coast (from north to south: Sinaloa, 20; Nayarit, 17; Colima, 2; Michoacan, 8; Guerrero, 10; Chiapas, 20). No questionnaires were answered in Oaxaca because we found no one that could be 
interviewed in the 2 locations we had time to visit, and Jalisco could not be visited due to the recent passing of Hurricane Patricia. Including the 20102011 surveys by I.M-L. and J.C.P-J., the total number of people interviewed during both campaigns was 833.

\section{Interviewee's ability to discriminate between species}

One of the key aspects of the surveys was to find out how well interviewees could distinguish between the 2 sawfish species. Their ability to discriminate between the 2 species was crucial to the reliability of the species-specific information generated.

Most interviewees (86\%) were able to identify either one or both species, $12 \%$ could not discriminate between them based on the pictures or matched the complete specimen photograph to the wrong rostrum photograph and $2 \%$ made incorrect identifications (choosing smalltooth sawfish as the species they caught in the Pacific). Overall, 55\% of interviewees correctly identified the largetooth sawfish (Fig. 2), $12 \%$ correctly identified the smalltooth sawfish, and $19 \%$ identified both species.

\section{Biology, ecology, and conservation status}

Age of interviewees and sawfish decline

Interviewee ages ranged from 24 to 92 years (mean = $62.4 \mathrm{yr}$ SD = $12.0 \mathrm{yr}$; Bonfil et al. 2017). Noticeably, the age distribution was strongly biased towards ages

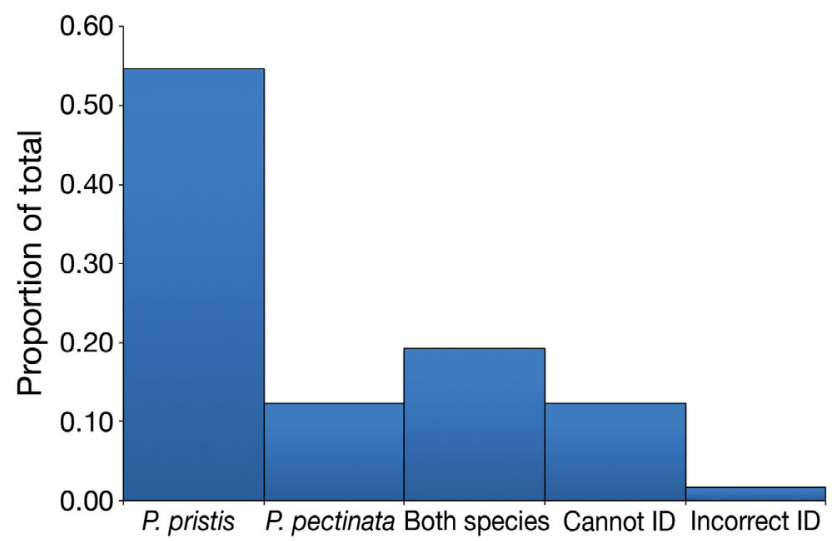

Fig. 2. Ability of questionnaire interviewees to identify the smalltooth sawfish Pristis pectinata and the largetooth sawfish $P$. pristis. The first 3 columns indicate the species identified. Cannot ID: interviewee unable to identify either species; Incorrect ID: one or both species incorrectly identified

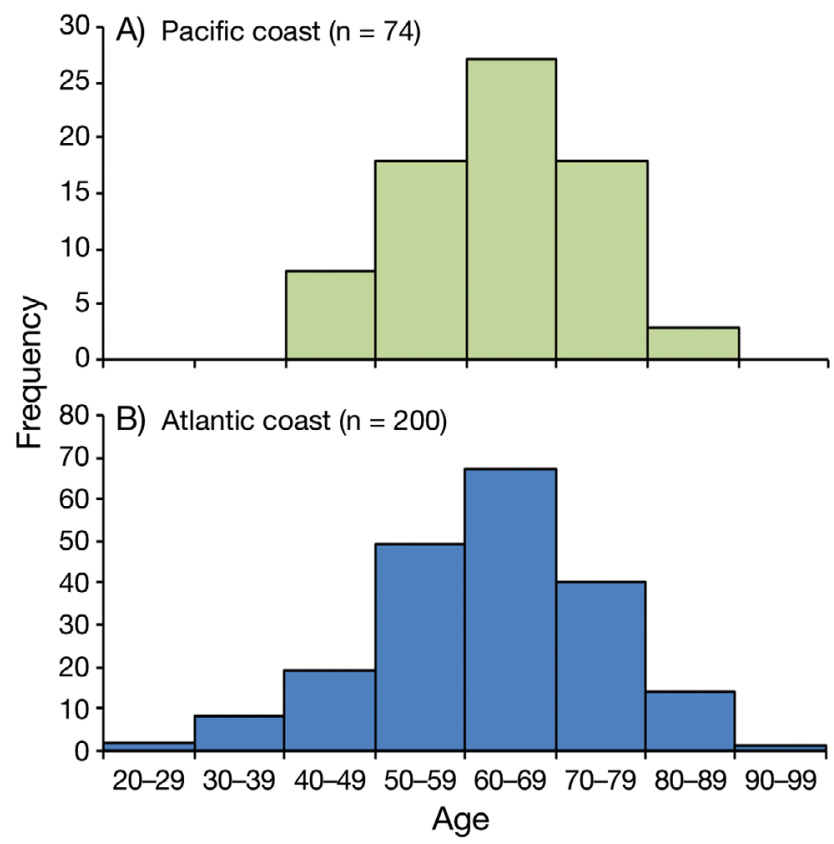

Fig. 3. Age distribution of interviewees (interviewees who had first-hand knowledge of sawfishes) on the (A) Pacific and (B) Atlantic coasts of Mexico

$>50$ yr and was similar along both coasts (Fig. 3). The large majority of fishers 20-49 yr old had never seen or caught a sawfish, while fishers with first-hand experience with sawfishes were largely $>50 \mathrm{yr}$ old. This pattern of interviewees who had encountered sawfishes being almost exclusively $>50 \mathrm{yr}$ was repeated in the age distribution of interviewees in all states surveyed (Fig. S4 in the Supplement).

\section{Dates of last sightings}

Data on the year of last sighting indicate that most frequently: interviewees last saw a smalltooth sawfish in the 1980s (mean $=1987, \mathrm{SD}=15.6 \mathrm{yr}$ ), interviewees last saw a largetooth sawfish on the Atlantic coast in the 1970s (mean $=1982, \mathrm{SD}=15.7 \mathrm{yr}$ ), interviewees last saw an unidentified sawfish on the Atlantic coast in the 1980s (mean = 1983, SD = 14.4 yr), and interviewees last saw a largetooth sawfish in the Pacific in the 1970s (mean $=1975, \mathrm{SD}=14.2 \mathrm{yr}$; Fig. 4). In the current decade, our data included only 3 sightings of the smalltooth sawfish, 5 of the largetooth sawfish and 5 of unidentified sawfishes on the Atlantic coast, and 1 of largetooth sawfish on the Pacific coast (Fig. 4).

Our data also suggested differential range contraction for each species. Last reported sighting information by state (Fig. S5 in the Supplement) showed 

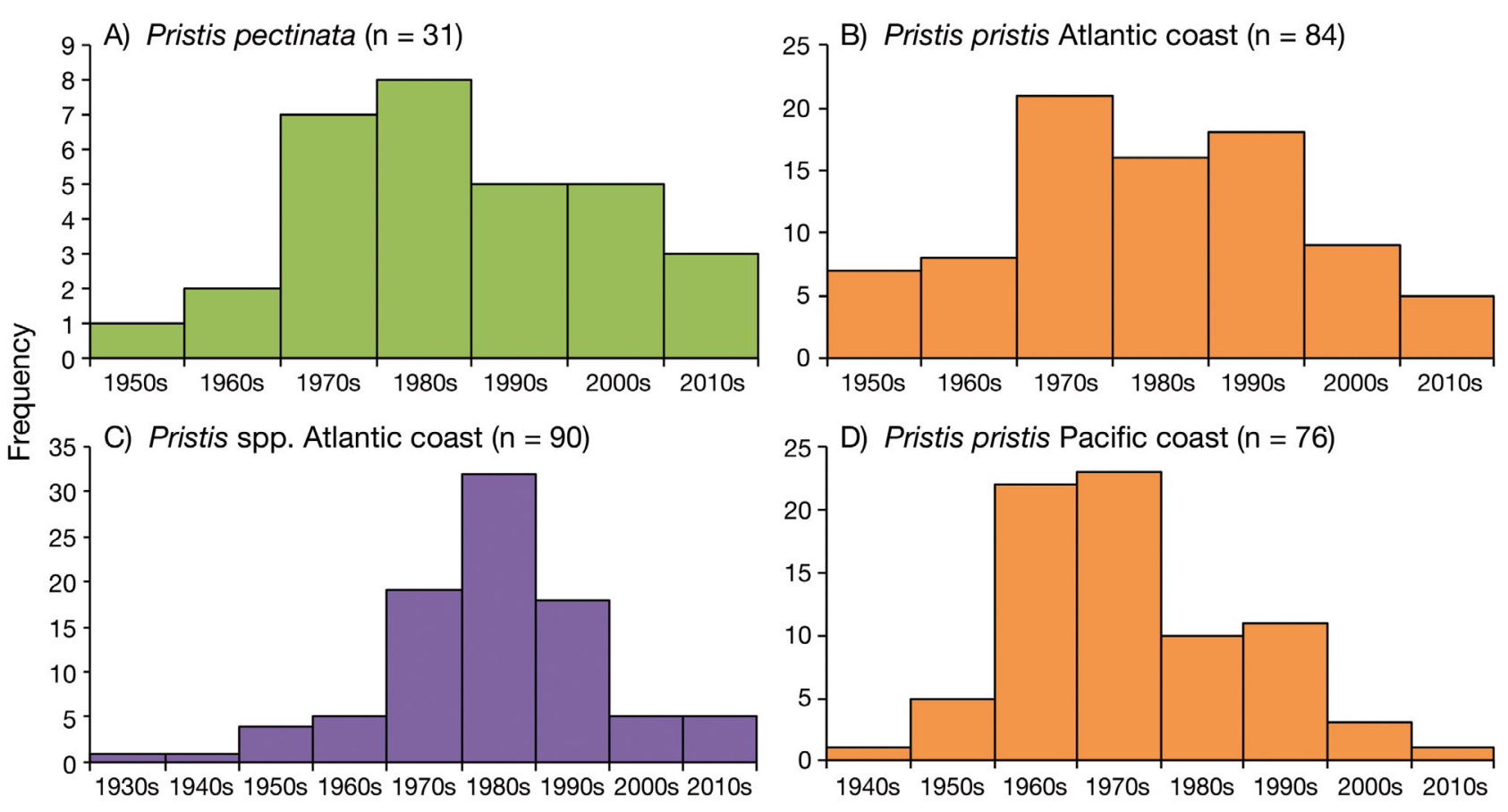

Decades

Fig. 4. (A-D) Frequency distributions showing answers to the question 'When was the last time you saw or caught a sawfish?' grouped by decade, for each species and coast. (C) shows answers given by interviewees who could not tell which of the 2 possible species they saw. Note that the smalltooth sawfish Pristis pectinata only occurs in the Atlantic Ocean

more recent reports of the smalltooth sawfish in Tamaulipas and Veracruz than other east coast states, although sample sizes were small and there was no information on the smalltooth sawfish for some states. In contrast, modal responses indicated that the largetooth sawfish was last seen in the 1970s in Tamaulipas and Veracruz, in the 1980s in Tabasco, and in Quintana Roo in the 1990s. Similarly, the largetooth sawfish might have disappeared first from its northernmost distribution limit on the Pacific coast (Fig. S5 in the Supplement). They have not been seen in Sinaloa since the late 1980s, while there were reports of this species in southern Pacific states in the 1990s, 2000s, and 2010s.

\section{Distribution}

Capture locality data were obtained from 3 sawfish rostra (1 Pristis pectinata from Quintana Roo, 2 $P$. pristis from Tabasco and Veracruz) in addition to those previously reported (Bonfil et al. 2017). The data showed that the smalltooth sawfish (Fig. S6 in the Supplement) was found in every Atlantic coast state, from Tamaulipas to Quintana Roo, with most records coming from Veracruz, Campeche, and Quintana Roo (see Fig. 6). These new data also indicated that the largetooth sawfish (Fig. S7 in the Supplement) occurred in most Atlantic coast states except Tamaulipas and Yucatan probably due to small sample sizes in both states, (but see 'Historic importance' below) and was found $200 \mathrm{~km}$ upstream in the Usumacinta River at least up to Emiliano Zapata, Tabasco. The largetooth sawfish was distributed in all Pacific coast states from Sinaloa to Chiapas.

\section{Historic importance}

The historic importance of sawfishes was estimated by asking interviewees how many sawfishes they had seen or caught in their life. Frequency distributions show that the most common responses at the national level (no species distinction) were 1 and 3-5 sightings per person (Fig. 5). However, there were several interviewees who saw 51-100 or >100 sawfishes in their life, suggesting that sawfishes were relatively common in some places, particularly in some river mouths and estuaries. For the Atlantic coast (no species distinction), the most common answer was 1 sawfish, followed by 3-5, while on the 

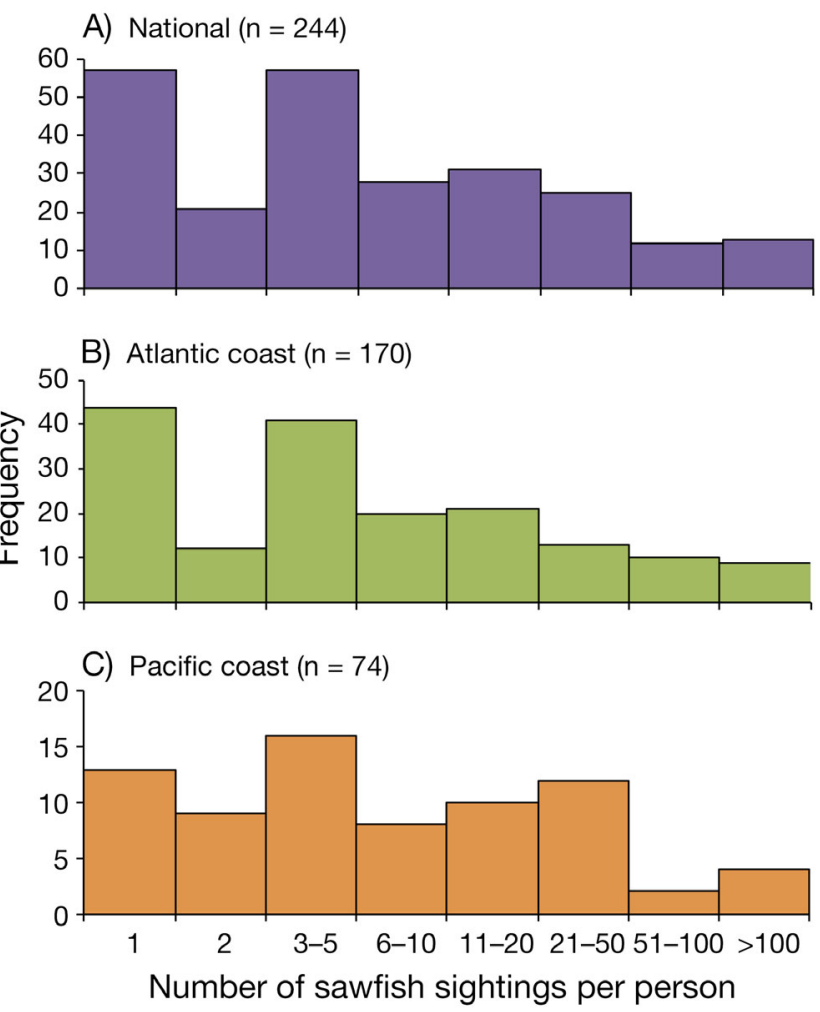

Fig. 5. Frequency distribution of total lifetime number of sawfish sightings by coast. Data are grouped in uneven size categories. (A) National total, both species combined; (B) Atlantic coast, both species combined; (C) Pacific coast, largetooth sawfish Pristis pristis only

Pacific coast the most common answer was $3-5$, followed by 1.

The same data by species and state suggests differences in importance between species and coasts (Fig. S8 in the Supplement). The most frequent response for the smalltooth sawfish was $3-5$, followed by 1 , and then $6-10$; however, several interviewees reported having seen $21-50,51-100$, or $>100$. The most frequent response for the largetooth sawfish on the Atlantic coast was 1 and 3-5, followed by 11-20, but several interviewees reported having seen 21$50,51-100$, or $>100$. On the Pacific coast, the most common answer was 3-5 for largetooth sawfish, followed by $21-50$.

The data on number of sawfishes seen in the life of interviewees were used to produce maps of historic importance by state for each species and coast (Fig. 6). The results suggest that the smalltooth sawfish was most common in Campeche, followed closely by Tabasco and Quintana Roo, and less common but present in all other states. On the Atlantic coast, the largetooth sawfish was also most common in Campeche, followed by Tabasco and Quintana Roo; they were slightly less common in Veracruz, and were rarest in Yucatan and Tamaulipas. On the Pacific coast, the largetooth sawfish was most common in Colima and Chiapas, slightly less common in Michoacan and Nayarit, and was rarest in Sinaloa and Guerrero.

\section{Community perception of the status of sawfishes in Mexico}

Interviewees were asked whether they thought sawfishes still occurred or had disappeared from the region. The proportion of fishers who believed that sawfishes still existed ( $51 \%$ ) was similar to those who believed they had disappeared $(47 \%)$; a small proportion were unsure about whether sawfishes could still be found $(2 \%)$. When data were analyzed by coast, a larger proportion of interviewees along the Atlantic coast thought that sawfishes still existed $(54 \%)$ vs. those on the Pacific coast (47\%).

\section{Sawfish biology and ecology}

Several questions in our survey were related to the biology and ecology of sawfishes (Supplementary Material in Bonfil et al. 2017). Sawfishes of all sizes were found primarily in shallow coastal waters, followed by estuaries, coastal lagoons, or deep coastal waters (Fig. 7). Juveniles were primarily found in shallow coastal waters or estuaries and coastal lagoons, followed by rivers. Adults were found primarily in shallow coastal waters followed by deeper coastal waters. Juveniles were more frequently reported associated with mangroves than sawfishes in general or adults. While some answers yielded useful data, we could not make inferences about local knowledge of recruitment.

Fishers' knowledge about feeding habits of sawfish was particularly enlightening given the scarcity of detailed scientific studies on this topic. According to their accounts, mullet Mugil spp., sardines (Clupeidae), snook Centropomus spp., and tarpon Megalops atlanticus were among the most common prey seen being hunted by sawfishes.

A total of 155 interviewees responded to questions about what sawfishes used their rostrum for. Of these, equal numbers ( $44 \%$ each) thought that sawfishes used their rostra to feed (kill or injure prey) and to defend themselves from predators; $12 \%$ said they used their rostra for both purposes. Of particular interest were 3 separate testimonies of fishers along the Atlantic coast who claimed to 

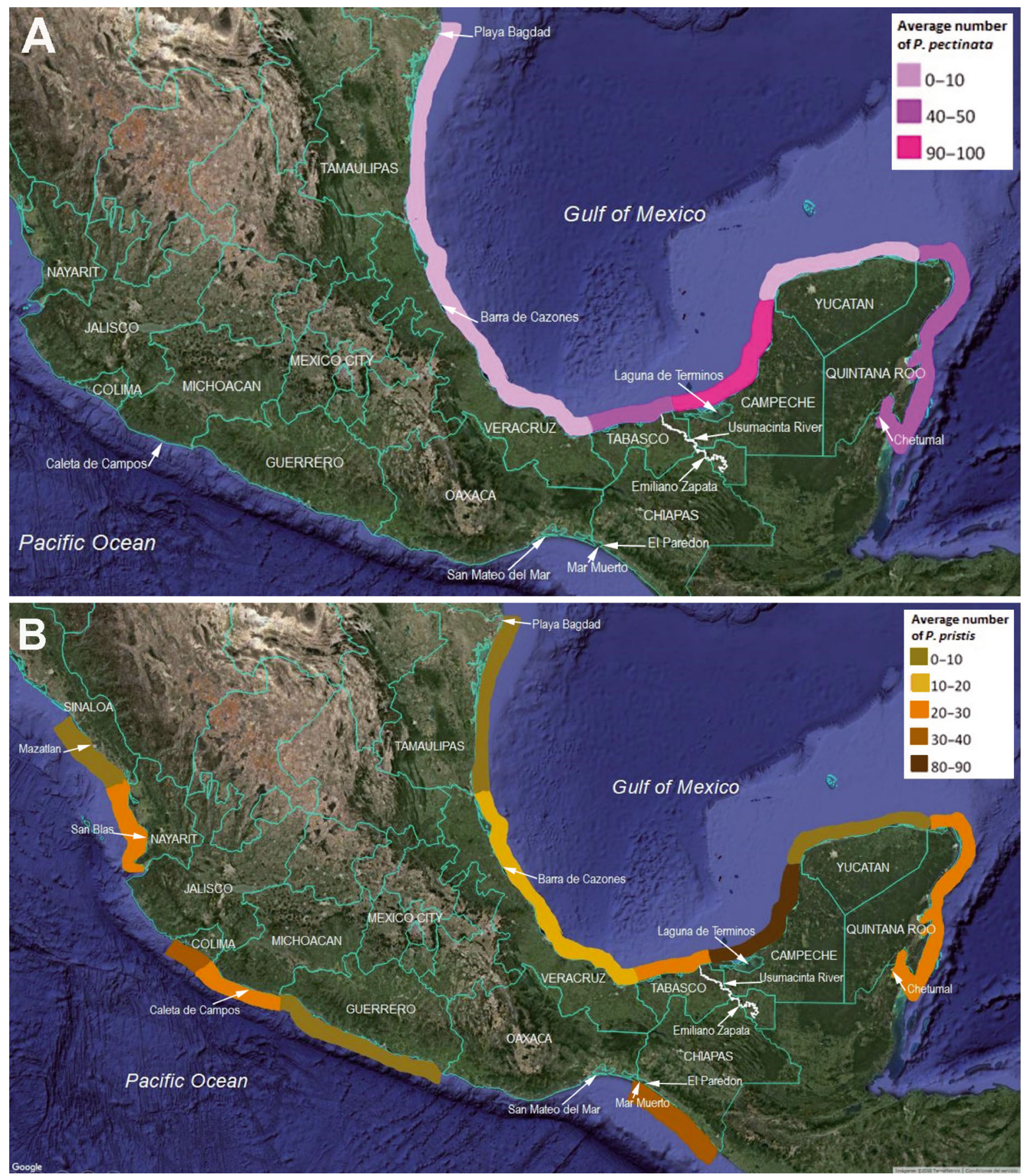

Fig. 6. Maps of historic importance (historic average of sawfish encounters) for (A) smalltooth sawfish Pristis pectinata in each state along the only coast where it was found (Atlantic) and (B) largetooth sawfish Pristis pristis in each state along the Atlantic and Pacific coasts. These data were based on the total number of sawfishes seen in the lifetime of interviewees; no data were obtained in Jalisco due to Hurricane Patricia, and in Oaxaca because of limited coverage and unavailability of fishers during our only visit there

have witnessed formidable battles in rivers between sharks (likely bull sharks Carcharhinus leucas) and large sawfishes; 1 of these interviewees said the sawfish would win in shallow water but the shark would win in deeper water. One inter- viewee claimed that sawfishes fought with crocodiles and another reported a fight between 2 sawfishes (possibly mating or mating competition) and described how he saw 2 large, entangled rostra above the surface of the water. 


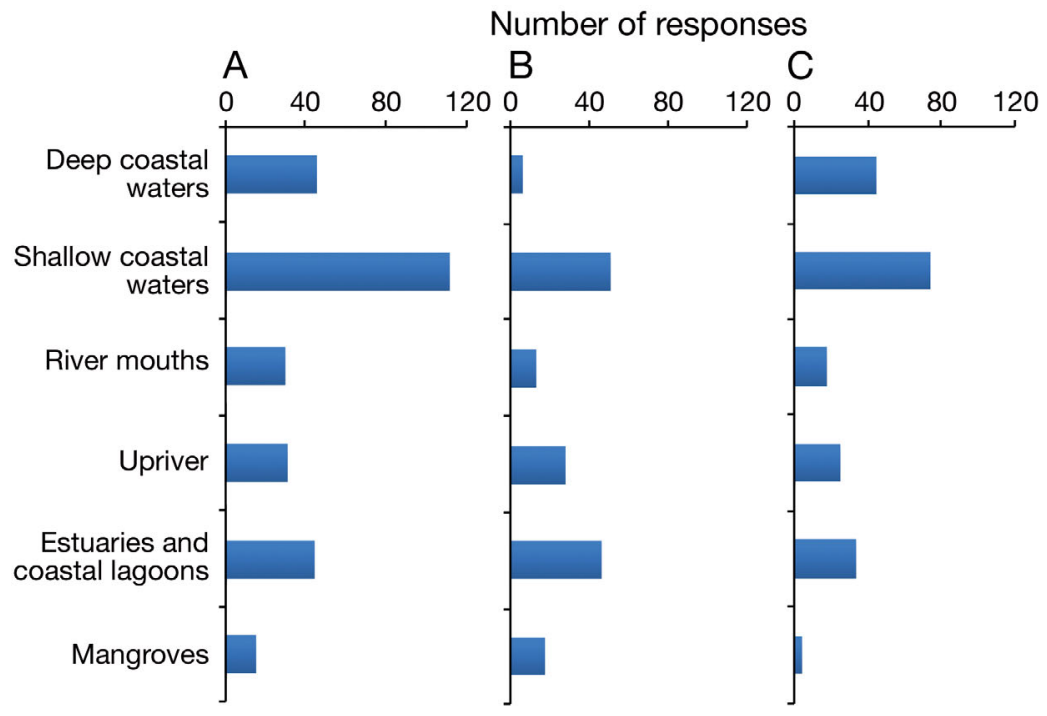

Fig. 7. Fishers' responses relating to sawfish habitat for (A) all sawfish combined; (B) juveniles $(<3 \mathrm{~m} \mathrm{TL})$; (C) adults $(\geq 3 \mathrm{~m}$ TL)

\section{Historical fisheries and importance of sawfishes to coastal communities}

Type of fishery

Sawfishes used to be a welcome, frequently used, and common catch in many coastal and inland fisheries, mostly but not exclusively, as bycatch. Our data show that sawfishes were caught and used all over Mexico and that about $2 / 3$ of all interviewees caught them as bycatch, 1/10 targeted them, and 1/4 discarded them dead or alive. This pattern was consistent on both coasts, with the percentage of interviewees targeting sawfishes being $7 \%$ on the Pacific coast and $11 \%$ on the Atlantic coast (Table 1). The percentages of interviewees using sawfishes when incidentally caught and not using them (killing them to disentangle them from nets, or releasing them alive) were respectively, $63 \%$ and $30 \%$ on the Pacific coast, and $65 \%$ and $24 \%$ on the Atlantic coast.

An old fisher in San Blas, Nayarit, gave an interesting and detailed report of how when he was a young boy (probably in the late 1940s), his godfather and uncle would take him sawfish fishing on a shallow bank a few kilometers from shore. They would paddle in a canoe, spot the sawfishes from the surface lying on the bottom in 15-20 $\mathrm{m}$ of water, target the females (he could not tell us how they discriminated the sexes from above) and once they found a fish they wanted to catch, they would sink a large and very sharp iron gaff tied to a rope, and place it a few meters to the side of the sawfish. Then they would slowly pull the gaff towards the sawfish to pull it with a jerk and insert it into the side of the sawfish. Once the sawfish had been fought to exhaustion, they would pull it to the side of the canoe, take its enormous liver (from which they could obtain 12 containers of oil, 201 in each), and discard the rest of the fish. This same fisher reported that in the 1960s another local fisher caught about 12 live largetooth sawfish for American entrepreneurs that took them in large tanks with water to the United States, presumably to aquaria there.

\section{Fishing gears}

Sawfishes used to be caught by Mexican fishers using all kinds of fishing gear that worked in shallow waters, including bays, estuaries, coastal lagoons, and rivers (Fig. 8). Not surprisingly, different kinds of entangling nets were by far the most common gear in which sawfishes were caught; however, they were also caught with hand lines, long-lines, trawl nets, harpoons, gaffs, and even cast nets (atarrayas). Two unusual methods employed to catch young juvenile sawfishes at the edge of rivers or lagoons were either grabbing them by hand from the tail, or using hand-made toy bows and arrows using old clothes' hangers. Such accounts are an indication of how common and easy to catch sawfishes were in the distant past.

Table 1. Type of historical fishery for sawfishes on both Mexican coasts expressed as proportion of responses. See Fig. 1 for locations. National total and coast subtotals are in bold

\begin{tabular}{|lcccc|}
\hline Locality & Incidental & Target & Unused & $\mathrm{n}$ \\
\hline Tamaulipas & 0.72 & 0.00 & 0.28 & 32 \\
Veracruz & 0.58 & 0.10 & 0.32 & 69 \\
Tabasco & 0.61 & 0.06 & 0.33 & 33 \\
Campeche & 0.71 & 0.17 & 0.13 & 48 \\
Yucatan & 0.75 & 0.25 & 0.00 & 4 \\
Quintana Roo & 0.70 & 0.19 & 0.11 & 27 \\
Atlantic coast & $\mathbf{0 . 6 5}$ & $\mathbf{0 . 1 1}$ & $\mathbf{0 . 2 4}$ & $\mathbf{2 1 3}$ \\
Sinaloa & 0.71 & 0.00 & 0.29 & 21 \\
Nayarit & 0.59 & 0.06 & 0.35 & 17 \\
Colima & 0.00 & 0.50 & 0.50 & 2 \\
Michoacan & 0.75 & 0.00 & 0.25 & 8 \\
Guerrero & 0.60 & 0.20 & 0.20 & 10 \\
Chiapas & 0.61 & 0.06 & 0.33 & 18 \\
Pacific coast & $\mathbf{0 . 6 3}$ & $\mathbf{0 . 0 7}$ & $\mathbf{0 . 3 0}$ & $\mathbf{7 6}$ \\
National total & $\mathbf{0 . 6 5}$ & $\mathbf{0 . 1 0}$ & $\mathbf{0 . 2 5}$ & $\mathbf{2 8 9}$ \\
\hline
\end{tabular}






Fig. 8. Relative importance of different fishing gears used to catch sawfishes nationally $(\mathrm{n}=381)$; similar trends were found on both coasts. 'Entangling nets' comprises all kinds of gillnets and beach seines

Nationwide, entangling nets (as defined here including: gillnets, trammel nets, beach seines, snook nets, mackerel nets, turtle nets, and shark nets) accounted for $66 \%$ of the reported gears used to catch sawfishes, followed by longlines and harpoons (Fig. 8). Entangling nets were slightly more common on the Atlantic coast (68 vs. $59 \%$ ); however, longlines and cast nets were about 2 times more common on the Pacific coast ( 9 vs. $18 \%$, and 3 vs. $7 \%$, respectively) and harpoons were more than twice as common on the Atlantic coast ( 7 vs. $2 \%$ ). Trawls represented only about $3 \%$ of the reported gears; however, our surveys focused on small-scale fishers and failed to include more than a few former or current shrimp-trawl fishers.

\section{Use and importance to coastal communities}

Sawfishes were used to various degrees when they were still regularly caught in coastal fisheries. Meat for human consumption was the most common use $(78 \%)$, followed by keeping rostra as trophies $(54 \%)$; however, the liver, fins, and skin were also used in smaller proportions (Fig. 9). There were some minor differences in sawfish use between coasts. Meat was used by $86 \%$ of interviewees on the Atlantic coast, but only by $59 \%$ on the Pacific coast; rostra were retained more on the Pacific coast $(61 \%)$ than the Atlantic coast (51\%). Interestingly, several old fishers from different localities reported a particular liking of sawfish meat, stating that it was 'sweet' and better than 'cazón' (i.e. sharks < 150 cm TL).

Despite the former widespread use of sawfishes, fishers' perception of how important sawfishes were to them indicates an apparent discordance. Only $42 \%$ of interviewees considered that sawfishes were important or of value to them. Sawfishes were con-



Fig. 9. Frequency distribution of interviewees' answers regarding use of sawfish parts nationally $(\mathrm{n}=170)$; similar trends were found on both coasts

sidered important to $43 \%$ of interviewees on the Atlantic coast and only $35 \%$ on the Pacific coast. Note that use figures provided above are based on a subset of 170 interviewees who said they used sawfishes and provided further details, while the figures for importance to fishers were based on a total of 214 interviewees answering if sawfishes were of value to them.

Most interviewees gave economic revenue as the main reason for the importance of sawfishes to them ( $55 \%)$, followed by using rostra as trophies or souvenirs $(19 \%)$. Personal consumption of meat accounted for $11 \%$ of responses, while being important because of their rarity and having very tasty flesh accounted for 9 and $6 \%$ of responses, respectively.

\section{Local names}

We recorded a total of 29 different local names for sawfishes (Table 2). By far the most common name was 'Pez Espada', an evident misnomer because this is also the common name of the swordfish Xiphias gladius. However, in the words of many coastal and riverine fishers, 'sawfishes have a sword-like snout surrounded by long teeth', thus the overlap.

'Pez Espada' was used on both coasts and in every state; other local names were also commonly used; however, some were exclusive to either the Pacific coast (e.g. 'Peine', 'Tejona', 'Tejón') or the Atlantic coast (e.g. 'Chavache', 'Peje Blanco', 'Serrucho'). Fishers in Quintana Roo were so familiar with sawfishes that they were the only ones to have specific names for each species and could distinguish them readily; they used 'Peje Blanco' or 'Pez Blanco' for the largetooth sawfish and 'Peje Espada' for the smalltooth sawfish. This reinforces the idea that both species were common in Quintana Roo in the past. 
Table 2. Common (local) names for sawfishes on each coast of Mexico. na, not applicable

\begin{tabular}{|c|c|c|c|c|}
\hline Local name & Literal translation & Frequency & Pacific & Atlantic \\
\hline Cazón de Diente & Tooth dogfish & 1 & & $\mathrm{X}$ \\
\hline Cazón Sierra & Saw dogfish & 1 & & $\mathrm{X}$ \\
\hline Chavache, Casvache & na & 5 & & $\mathrm{X}$ \\
\hline Espada & Sword & 1 & $\mathrm{X}$ & \\
\hline Peine, Pez Peine, Pescado Peine & Comb, comb fish & 16 & $\mathrm{X}$ & \\
\hline Peinuda, Peinudo & Combish & 2 & $\mathrm{X}$ & \\
\hline Peja, Pez Peja & na & 4 & & $\mathrm{X}$ \\
\hline Peje Blanco ${ }^{a}$, Pez Blanco ${ }^{a}$ & White fishe, white fish & 6 & & $\mathrm{X}$ \\
\hline Peje Espada ${ }^{b}$ & Swordfishe & 7 & & $\mathrm{X}$ \\
\hline Pez Espada & Swordfish & 124 & $\mathrm{X}$ & $\mathrm{X}$ \\
\hline Pez Martillo & Hammerfish & 1 & $\mathrm{X}$ & \\
\hline Pez Serrucho, Serrucho & Handsaw, handsaw fish & 11 & & $\mathrm{X}$ \\
\hline Pez Sierra & Sawfish & 42 & $\mathrm{X}$ & $\mathrm{X}$ \\
\hline Pez Vela & Sailfish & 1 & & $\mathrm{X}$ \\
\hline Tejona, tejón, tejonuda & Badger & 9 & $\mathrm{X}$ & \\
\hline Tiburón & Shark & 1 & & $\mathrm{X}$ \\
\hline Tiburón Peine & Comb shark & 2 & $\mathrm{X}$ & \\
\hline Tiburón Serrucho & Handsaw shark & 1 & & $\mathrm{X}$ \\
\hline Tiburón Sierra & Saw shark & 10 & $\mathrm{X}$ & $\mathrm{X}$ \\
\hline Tiiburón Espada & Sword shark & 5 & $\mathrm{X}$ & $\mathrm{X}$ \\
\hline
\end{tabular}

Perceptions of the danger represented by sawfishes

Of the 201 interviewees who responded to the question of whether sawfishes were considered dangerous, $62 \%$ thought they were dangerous and $49 \%$ gave details of why. However, $74 \%$ of those giving details said they were dangerous because they defended themselves when attacked by fishers. We found at least 3 fishers who claimed to have been injured by or witnessed someone else being hurt by a sawfish, and 11 accounts of sawfishes damaging wooden boats with their rostra. One interviewee reported that sawfishes were dangerous to cattle, injuring them in the legs when crossing creeks (ostensibly when cattle stepped on them or disturbed them while resting on the bottom).

\section{Cultural value of sawfishes, myths, and traditions}

In the Wave communities of the eastern Oaxacan coast, we found the only evidence of the current cultural value of sawfishes in Mexico. Unfortunately, we could only visit 2 villages in this state and at a time when fishers were not available. In the village of San Mateo del Mar, there is an ancient 'dance of the sawfish' with its specific traditional music, and locals keep 2 ancient largetooth sawfish rostra which are used as sacred relics in traditional religious cere- monies (Fig. S9 in the Supplement). During the Pascua season, large parades pass through the village streets carrying the 2 rostra at the front, and there are school murals depicting this and other local traditions (Fig. S10 in the Supplement).

A few of the interviewees reported traditional beliefs that ground sawfish rostra was a remedy for asthma and cancer, and 1 person reported that the oil extracted from the skins was used to cure fly bites in calves.

\section{DISCUSSION}

Similar LEK approaches have been used to assess the status and historical presence of sawfishes in regions or entire countries in several parts of the world (Seitz \& Poulakis 2002, 2006, Poulakis \& Seitz 2004, Wiley \& Simpfendorfer 2010, Giglio et al. 2015, Hossain et al. 2015, Leeney \& Poncelet 2015, Leeney \& Downing 2016, Reis-Filho et al. 2016, Leeney 2017). Given the dire conservation status of sawfishes worldwide (Dulvy et al. 2016), in-depth approaches like the one used here should be encouraged to assess the conservation status of this family throughout its global distribution and to recover valuable LEK information that may eventually be lost. Such studies would help obtain an updated status assessment of sawfishes worldwide and provide key information to shape fu- 
ture conservation and research actions. Some of the advantages of LEK surveys are that they are an easy, rapid, and relatively inexpensive way to obtain relevant information otherwise unavailable to science.

\section{Interviewees' ability to discriminate between species}

While Mexican fishers showed an ability to discriminate sawfish species, fishers in Bangladesh were unable to distinguish between Pristis species (Hossain et al. 2015). Whether this reflects real between-country differences in fishers' abilities to identify aquatic fauna or is due to methodological differences among studies is not clear. We presented interviewees with detailed photographs of the rostra and the entire animal to facilitate identification, and noted that the rostrum photograph was usually more helpful to them. Fishers often attempted identification using the entire animal color, which varies depending on freshness of specimens and settings during photography and printing; however, once they saw the rostrum photographs, they assigned species with more assertion. Other sawfish studies did not attempt to distinguish LEK information by species (e.g. Leeney \& Poncelet 2015, Giglio et al. 2016, Leeney 2017); if possible, such loss of opportunity should be avoided in the future. Our results, although not perfect, show that it is possible to recover some species-specific information in regions where multiple species are found, something that is critical for future conservation and recovery plans.

\section{Distribution, biology, ecology, and conservation status}

Survey data include indicators of the past occurrence and historic importance of each species, as well as the current status of sawfishes in Mexico. These suggest that sawfishes were widespread and common along both coasts of Mexico, but that they declined in abundance between the 1960s and 1980s and that they are currently nearly extirpated.

Age of interviewees, dates of last sightings, and sawfish decline

Leeney \& Poncelet (2015) found a similar pattern in Guinea Bissau to what we saw in Mexico, where only fishers >40-50 yr old knew sawfishes first-hand.
Leeney \& Downing (2016) also report younger fishers not knowing sawfishes in Gambia, and Leeney (2017) reported that the majority who knew sawfishes in Mozambique were > 30 yr old.

Interviewees' age can be a measure of the timing of decline in Mexican waters and suggests that populations of both species have virtually disappeared. If fishers $<50$ yr old have hardly seen a single specimen in their lives, then sawfishes began to be uncommon in Mexico some 40 yr ago (Bonfil et al. 2017). At present, sawfishes seem to be so rare that we could only find 2 fishers in their 20s who claim to have seen sawfishes personally along the Atlantic coast. Remarkably, there was no one $<40$ yr old who had first-hand experience with sawfishes in any state on the Pacific coast (Fig. S4 in the Supplement), suggesting that the largetooth sawfish declined there earlier than sawfishes on the Atlantic coast. Similar declines in sawfish abundance in the Arabian region were also reported for the 1970s-1980s (Moore 2015) providing stronger evidence of a link between the global monofilament gillnet boom and sawfish declines worldwide (see 'Fisheries and associated gear' below).

Our data suggest 3 main conclusions: (1) sawfishes have become increasingly scarce along both coasts, (2) the largetooth sawfish declined earlier on the Pacific coast than either species on the Atlantic coast, and (3) the likelihood of the largetooth sawfish still existing on the Pacific coast is smaller than the likelihood of either species still existing on the Atlantic coast.

Some of these perceptions are supported by documented records obtained during this survey, which placed the last smalltooth sawfish sighting in Tamaulipas between 2008 and 2009 (dry specimen seen), and the last largetooth sawfish sightings in Chetumal, Quintana Roo in 1998 and in Caleta de Campos, Michoacan in 2010 (photograph seen). Bonfil et al. (2017) reported the capture of a live juvenile female smalltooth sawfish in Barra de Cazones, Veracruz on 20 January 2016. According to growth rates in Scharer et al. (2012), this specimen was likely just over 1 yr old when caught, and was probably born in Mexican waters, since smalltooth sawfish are not highly migratory (Carlson et al. 2014). Thus, this sawfish might have a philopatric mother and several siblings somewhere in Mexico (Feldheim et al. 2017), suggesting that recovery of the species might be still possible.

The slight trend of geographical range contraction suggested here for largetooth sawfish along the Atlantic coast from north to south is consistent with 
ecological theory (MacCall 1990) and the known historical distribution of this species. The largetooth sawfish had its western North Atlantic distribution limit in the northern Gulf of Mexico (FernandezCarvalho et al. 2014) and it would be expected that as their population collapsed, their range shrank towards their former center of distribution along the coasts of Nicaragua and Costa Rica where habitat suitability is theoretically optimal (MacCall 1990).

\section{Distribution and historic importance}

The historic presence of the largetooth sawfish in the Gulf of California and along the coast of Baja California is uncertain. There are no verifiable reports of sawfishes there; in fact, the only 2 museum records known to us are dubious. An isolated rostrum at the Smithsonian Museum of Natural History is labeled only as from 'California' and attributed to 'Baja, Mexico?' or to 'Gulf of California?' (Faria et al. 2013). In addition, a Los Angeles County Museum photograph of a rostrum is said to come from Baja California, Mexico, with no further locality data (Faria et al. 2013). However, it is noteworthy that, to our knowledge, no surveys for sawfishes have been carried out within the Gulf of California; thus, the historic presence of the largetooth sawfish there might be waiting to be unveiled by dedicated research.

A possible interpretation of the difference in importance between species and coasts suggested by the data is that perhaps the largetooth sawfish occurred in higher densities on the Pacific coast than either species on the Atlantic coast; however, this is difficult to discern. It should be noted that a few fishers on the Pacific coast reported seeing over 500 and even over 1000 sawfishes in their lifetime.

The historic importance of the smalltooth sawfish as estimated here is somewhat in contradiction with data on sampled trophy rostra that show most records coming from Veracruz (Bonfil et al. 2017). These differences are likely due to the current availability of trophies, rather than the historic importance of the species. In other words, the former importance of both species at each location might have no relation to how many owners in each location have kept trophy rostra to the present day or how long they have kept them.

The maps of historic importance for both species along the Atlantic coast (Fig. 6) seem to be accurate estimates considering that Laguna de Terminos in Campeche might have been a major center of abundance for both species (Carranza 1959, Zarur-Menez
1962). In addition, Tamaulipas is closer to the northernmost distribution limit of the largetooth sawfish and consequently its abundance should be expected to have been lower there than in southern latitudes. Also, the largetooth sawfish is typically associated with rivers and river mouths (Fernandez-Carvalho et al. 2014), and would be expected to have been less abundant in Yucatan due to the lack of rivers there. With no previous information existing, these are the first available data, and represent the only baseline information on the relative importance of both species in Mexico. The most important aspect of this analysis was that both species seem to have been fairly common in the past, in stark contrast with their current status.

\section{Community perception of the status of sawfishes}

Our results are somewhat difficult to reconcile with other data gathered during the surveys, which show that the great majority of fishers have not encountered a sawfish in the last 15 yr (see Fig. 4 and 'Dates of last sightings' section). Yet, about half of interviewees thought that sawfishes have not disappeared. This suggests denial on the part of the fishers regarding the precarious conservation status of sawfishes in the face of evidence (as per their own daily experience at sea). Further sociological and psychological efforts are probably required to properly explain this situation. However, interviewees on the Pacific coast seemed more conscious of the actual state of sawfish populations when compared with interviewees on the Atlantic coast; this seems somewhat in agreement with data presented above that suggest sawfishes declined earlier on the Pacific coast.

A similar study carried out in Bangladesh, where sawfishes have also suffered strong declines but still exist ( 3 species) showed that a large proportion of fishers were somewhat conscious of the conservation situation of sawfishes there and thought they were heavily declining (Hossain et al. 2015).

\section{Biology and ecology}

Interviewee knowledge about sawfish habitat use was consistent with the literature (Thorson 1974, 1976, 1982, Poulakis et al. 2011, Carlson et al. 2014, Guttridge et al. 2015). Undoubtedly, fishers that were alive when sawfishes were still plentiful in Mexico had a keen understanding of the basic habitats used by sawfishes, such as their preference for shallow 
coastal waters rather than deep coastal waters, or juveniles occurring more frequently in estuaries and coastal lagoons than any other habitat. This highlights the importance of continuing to collect fishers' knowledge to learn about these species.

Poulakis et al. (2017) analyzed stable isotopes from fin clips of $>200$ smalltooth sawfish and also fecal samples from 4 individuals from Florida and reported a diet based on teleosts and batoids. Notably, they identified striped mullet Mugil cephalus, Clupeiformes, and Carangidae as part of the diet. Our data suggest that fisher's knowledge of sawfish diet is reasonably good; the lack of snook and tarpon in the fecal samples could be explained by the small sample size of Poulakis et al. (2017) or the low importance of these species in their study area. Several fishers related how they used to see sawfishes slash through schools of fishes in estuaries or river mouths to feed, hitting some fishes during the slashing and then turning back to pick them up once dead or injured. This is in agreement with current knowledge about sawfish feeding techniques (Breder 1952).

Interviewee accounts of sawfish intra- and interspecific interactions are likely to epitomize true former ecological relationships between these species when habitats were pristine or at least minimally impacted by human activities such as changes in river flow, pollution, habitat destruction, coastal development, increased boat traffic, and especially overfishing.

\section{Historical fisheries, use, and importance of sawfishes to coastal communities}

\section{Fisheries and associated gear}

As has been documented globally, it is clear that sawfishes were mostly an appreciated bycatch species in Mexico, although targeted fisheries also existed (Bonfil et al. 2017). However, the widespread existence of targeted fisheries for sawfishes in the past is surprising. Notably, targeted fisheries were important along the Atlantic coast in Yucatan $(25 \%$ of interviewees), Quintana Roo (19\%), and Campeche (17\%), as well as on the Pacific coast in Colima $(50 \%$ of interviewees), and occurred in nearly every state except Tamaulipas, Sinaloa, and Michoacan.

One of the few published accounts of targeted sawfish fisheries in Mexico comes from a natural resources survey from the mid-1950s (Beltrán 1959). Carranza (1959) surveyed the fisheries of the Yucatan Peninsula from August 1954 to August 1955 and recounts that in those years, artisanal fishers from Laguna de Terminos in Campeche caught large quantities of smalltooth sawfish, which was one of the most lucrative fisheries there between December and February, and that both sawfish species were abundant and potentially important fishery resources along the northern Yucatan Peninsula. Sawfishes were caught with harpoons and gillnets, the meat was sent fresh or salted to the interior of Mexico, and the liver was used for the production of oil. Interestingly, he reported that the fins of sawfishes were not sold to shark fin buyers because 'they contained scant quantities of gelatin'.

Perhaps the most well-documented sawfish fishery occurred in Lake Nicaragua for the largetooth sawfish (Thorson 1982). Not surprisingly, neither that fishery nor those in Mexico were sustainable and contributed to sawfish declines along the Atlantic coast of Central America.

Our data strongly suggest that the large amounts of entangling nets of all kinds and materials that have existed in Mexican coastal waters were and continue to be the major reason for the decline of smalltooth and largetooth sawfish populations, and will be the main impediment to their recovery. Bonfil et al. (2017) arrived at a similar conclusion, and previous studies in other parts of the world have also suggested that the widespread use of monofilament and other kinds of gillnets is the major threat to sawfishes globally (Seitz \& Poulakis 2006, Giglio et al. 2015, Hossain et al. 2015, Leeney \& Poncelet 2015, Moore 2015, Reis-Filho et al. 2016). Still, our data show that they also used to be fished with unconventional methods such as gaffs, harpoons, cast nets, and even by hand; similarly, Leeney \& Poncelet (2015) reported fishers in Guinea Bissau harpooning sawfishes from shore, as they were so abundant in the past.

There is little doubt that if our survey were expanded to include the trawl-fishing industry, the importance of trawls in the former catches of sawfishes would increase considerably. Trawls are thought to have played an important role in the decline of sawfish populations in Mexico (Bonfil et al. 2017).

\section{Use and importance to coastal communities}

Our results suggest that sawfish meat was a readily available source of protein and an appreciated product in some local communities. In the Laguna de Terminos, Campeche, it was shipped salt-dried or fresh to larger urban centers in the 1950s (Carranza 
1959). Notably, a few interviewees mentioned local beliefs that dried sawfish rostra had medicinal powers against asthma and even cancer.

Fortunately, our data suggest that local fishers were unaware of the high value of sawfish fins on the Asian elasmobranch fin market (McDavitt 2014); this lack of awareness might have meant that there was little incentive to find and kill sawfishes. This is likely due to fins not being known locally as highly prized back in the 1940s-1950s when sawfishes were readily abundant and regularly caught.

There are few comparable studies with which to contrast our data. Moore (2015) reports the oocytes of sawfish as a local delicacy in the Arabian region and Leeney \& Poncelet (2015) mention sawfish as a highly regarded food in Bijagos, Guinea Bissau. Similar reports in the literature show that in Bangladesh, sawfishes were thought to have medicinal value and cure lower back pain, all kinds of diseases and protect from evil, among other things (Hossain et al. 2015). McDavitt (2014) reported that sawfishes were symbols of impartial justice in West Africa and protectors of humanity for tribes on the Atlantic coast of Panama. There is a need to conduct more in-depth surveys along the former range of sawfishes to recover information about the past relationship between coastal communities and sawfishes. This is not only useful as anthropological testimony but could guide future conservation and recovery plans that take into account the needs and views of human coastal populations. Without the committed and dedicated participation of local communities, recovery will be nearly impossible.

Perceptions of the danger represented by sawfishes

Our results show that the most common opinion among fishers was that sawfishes were only dangerous when disturbed or attacked. This perception is in agreement with known sawfish behavior as an elasmobranch not prone to carry out unprovoked attacks on people.

\section{CONCLUSIONS}

Several data sources presented here strongly suggest that the smalltooth and largetooth sawfish are in a dire situation in Mexican waters. The relatively old age of fishers that have seen sawfishes first-hand, the large number of years since the last sighting of sawfishes by interviewees, and the significant contrac- tion of their former distribution given the lack of documented reports in the last decade (with the caveat that no scientific party has actively searched for them yet) all point towards the same conclusion: the smalltooth sawfish is extremely rare and might be nearly extirpated and the largetooth sawfish might already be extirpated from both Mexican coasts.

Mexican legislation for conservation of endangered species (NOM-059-SEMARNAT-2010; Official Diary of the Federation 2010) currently classifies both species as 'threatened'. The data provided here show that both species should be urgently re-categorized as 'endangered'.

Future work towards the conservation and recovery of sawfishes in Mexico should be conducted, aiming to actively look for remnant populations or isolated individuals. Areas of former importance such as those highlighted here (coasts of Campeche, Tabasco, and Quintana Roo for both species, and coasts of Nayarit, Colima, and Chiapas for the largetooth sawfish) should be a priority. In addition, it would be important to search coastal areas that have been less affected by human development and habitat destruction, such as coastal biosphere reserves, national parks, and areas for the protection of flora and fauna. The fact that a juvenile smalltooth sawfish has been recently caught alive gives hope that it may not be too late, at least for that species.

Given the likely low abundance of both species in Mexican waters, the use of environmental DNA (Simpfendorfer et al. 2016) should be a priority methodology to search for sawfishes, together with traditional scientific methods such as netting for juveniles, hooked gears for larger individuals, and use of unmanned aerial vehicles (drones) in waters with sufficient clarity for aerial location. Linking realtime LEK data to scientific research efforts will maximize successful outcomes (e.g. Poulakis et al. 2011).

Sawfishes were fished with all kinds of gears but they were caught primarily with gillnets. Those captured were almost universally killed and consumed for food or trophies. Changing these old habits among coastal communities and offering alternatives will be paramount in conservation and recovery plans for sawfishes in Mexico. Increased and effective enforcement of gillnet and other fishing gear bans in natural protected areas is another area in need of improvement (Bonfil et. al 2017), and one which would have a direct impact on future efforts for the recovery of sawfishes. Environmental education efforts that stress the ecological importance of sawfishes for healthy coastal ecosystems, as well as their cultural value for ancient and current Mexican 
peoples will improve the chances of community support for recovery efforts.

Information about LEK and the current status of sawfishes is lacking for most of Latin America, with the exception of parts of Brazil (Giglio et al. 2015, 2016, Reis-Filho et al. 2016), as well as in other parts of the world. This highlights the need to expand efforts for the assessment of the conservation status of sawfish species in the region. Our questionnairebased intensive survey approach can be replicated rapidly and relatively cheaply in other Central and South America countries, as well as elsewhere in the former range of sawfishes.

Acknowledgements. This study was financed by the Comisión Nacional de Áreas Naturales Protegidas (CONANP), of the Secretaría del Medio Ambiente y Recursos Naturales, Project PROCER/DGOR/03/2015. We thank Ana Rebeca Barragán Rocha formerly of CONANP for continuous support of this project and guidance through the bureaucracy maze. We also thank Raúl Villaseñor Talavera and the Comisión Nacional de Pesca y Acuacultura (CONAPESCA) for facilitating the collaboration of sub-delegates of CONAPESCA in every state visited, to meet groups of fishers for interviews. Victor Antonio Zamora Rodríguez was particularly helpful for organizing fishers in Acapulco, Guerrero. A great thank you goes to all the fishers who kindly shared their experiences and day-to-day knowledge about sawfishes, and to all the owners of sawfish rostra who allowed us to measure and sample their trophies, and who shared with us the stories behind them. Ivet Valladolid Salazar prepared the maps. This work was presented as part of the symposium 'Biology and Ecology of Sawfishes' at the 2016 annual meeting of the American Elasmobranch Society, which was supported by funding from the Save Our Seas Foundation, Disney Conservation Fund, and the American Elasmobranch Society. Publication costs were provided by the Save Our Seas Foundation

\section{LITERATURE CITED}

Beltrán E (ed) (1959) Los Recursos Naturales del Sureste y su Aprovechamiento. III Parte, Estudios Particulares Tomo 3o. Instituto Mexicano de Recursos Naturales Renovables A. C., Mexico DF

Bonfil R, Mendoza-Vargas OU, Ricaño-Soriano M, PalaciosBarreto PY, Bolaño-Martínez N (2017) Former widespread abundance and recent downfall of sawfishes in Mexico as evidenced by historical photographic and trophy records. Fisheries (Bethesda, Md) 42:256-259

Breder CM (1952) On the utility of the saw of the sawfish. Copeia 1952:90-91

* Carlson JK, Gulak SJB, Simpfendorfer CA, Grubbs RD and others (2014) Movement patterns and habitat use of smalltooth sawfish, Pristis pectinata, determined using pop-up satellite archival tags. Aquat Conserv 24:104-117

Carranza J (1959) Pesca y Recursos Pesqueros In: Beltrán E (ed) Los Recursos Naturales del Sureste y su Aprovechamiento. III Parte, Estudios Particulares Tomo 3o. Instituto Mexicano de Recursos Naturales Renovables, A. C., Mexico DF, p 151-238
Carreras C, Cardona L, Aguilar A (2004) Incidental catch of the loggerhead turtle Caretta caretta off the Balearic Islands (western Mediterranean). Biol Conserv 117: 321-329

Castro-Aguirre JL, Espinosa Pérez H (1996) Listados Faunísticos de México. Vol 7, Catálogo sistemático de las rayas y especies afines de México: Chondrichthyes: Elasmobranchii: Rajiformes: Batoideiomorpha. Instituto de Biología UNAM, Mexico City

* Dulvy NK, Davidson LNK, Kyne PM, Simpfendorfer CA and others (2016) Ghosts of the coast: global extinction risk and conservation of sawfishes. Aquat Conserv 26: $134-153$

Faria VV, Mcdavitt MT, Charvet P, Wiley TR and others (2013) Species delineation and global population structure of Critically Endangered sawfishes (Pristidae). Zool J Linn Soc 167:136-164

Feldheim KA, Fields AT, Chapman DD, Scharer RM, Poulakis GR (2017) Insights into reproduction and behaviour of the smalltooth sawfish Pristis pectinata. Endang Species Res 34:463-471

*Fernandez-Carvalho J, Imhoff JL, Faria VV, Carlson JK, Burgess GH (2014) Status and the potential for extinction of the largetooth sawfish Pristis pristis in the Atlantic Ocean. Aquat Conserv 24:478-497

*Giglio VJ, Luiz OJ, Gerhardinger LC (2015) Depletion of marine megafauna and shifting baselines among artisanal fishers in eastern Brazil. Anim Conserv 18:348-358

Giglio VJ, Luiz OJ, Reis MS, Gerhardinger LC (2016) Memories of sawfish fisheries in a southwestern Atlantic estuary. SPC Traditional Marine Resource Management and Knowledge Information Bulletin 36:28-32

* Guttridge TL, Gulak SJ, Franks BR, Carlson JK and others (2015) Occurrence and habitat use of the critically endangered smalltooth sawfish Pristis pectinata in the Bahamas. J Fish Biol 87:1322-1341

Guzmán AF, Meráz-Munguía MA (2013) Vertebrados condríctios de la colección del Laboratorio de Ecología de la Escuela Nacional de Ciencias Biológicas, Instituto Politécnico, Nacional, México. CICIMAR Oceánides 28: 41-60

Harrison LR, Dulvy NL (eds) (2014) Sawfish: a global strategy for conservation. IUCN Species Survival Commission's Shark Specialist Group, Vancouver

Herrera AL (1896) Catálogo de la colección de los peces del Museo Nacional. Imprenta del Museo Nacional, México 6:1-87

* Hossain MA, Thompson BS, Chowdhury GW, Mohsanin S, Fahad ZH, Koldewey HJ, Islam MA (2015) Sawfish exploitation and status in Bangladesh. Aquat Conserv 25:781-799

*Leeney RH (2016) Fishers' ecological knowledge of sawfishes in Lake Piso, Liberia. Aquat Conserv 26:381-385

*LLeeney RH (2017) Are sawfishes still present in Mozambique? A baseline ecological study. PeerJ 5:e2950

KLeeney RH, Downing N (2016) Sawfishes in the Gambia and Senegal: shifting baselines over 40 years. Aquat Conserv 26:265-278

* Leeney RH, Poncelet P (2015) Using fishers' ecological knowledge to assess the status and cultural importance of sawfish in Guinea-Bissau. Aquat Conserv 25:411-430

MacCall AD (1990) Dynamic geography of marine fish populations. Washington Sea Grant Program, Seattle, WA

McDavitt MT (2014) Sawfish products and trade. In: Harrison LH, Dulvy NK (eds) Sawfish: a global strategy for 
conservation. IUCN Shark Specialist Group, Vancouver, p 72-75

Moore ABM (2015) A review of sawfishes (Pristidae) in the Arabian region: diversity, distribution, and functional extinction of large and historically abundant marine vertebrates. Aquat Conserv 25:656-677

Official Diary of the Federation (2010) Environmental protection - wild native Mexican species of flora and fauna - risk categories and specifications for their inclusion, exclusion, or change-list of species at risk. Government of Mexico, Mexico City

Poulakis GR, Seitz JC (2004) Recent occurrence of the smalltooth sawfish, Pristis pectinata (Elasmobranchiomorphi: Pristidae), in Florida Bay and the Florida Keys, with comments on sawfish ecology. Fla Sci 67:27-35

Poulakis GR, Stevens PW, Timmers AA, Wiley TR, Simpfendorfer CA (2011) Abiotic affinities and spatiotemporal distribution of the endangered smalltooth sawfish, Pristis pectinata, in a south-western Florida nursery. Mar Freshw Res 62:1165-1177

Poulakis GR, Urakawa H, Stevens PW, DeAngelo JA and others (2017) Sympatric elasmobranchs and fecal samples provide insight into the trophic ecology of the smalltooth sawfish. Endang Species Res 32:491-506

Reis-Filho JA, Freitas RH, Loiola M, Leite L and others (2016) Traditional fisher perceptions on the regional disappearance of the largetooth sawfish Pristis pristis from the central coast of Brazil. Endang Species Res 29: $189-200$

Robillard M, Séret B (2006) Cultural importance and decline of sawfish (Pristidae) populations in West Africa. Cybium 30(Suppl):23-30

Scharer RM, Patterson WF III, Carlson JK, Poulakis GR (2012) Age and growth of endangered smalltooth sawfish (Pristis pectinata) verified with LA-ICP-MS analysis of vertebrae. PLOS ONE 7:e47850

Schmitter-Soto JJ, Vásquez-Yeomans L, Pimentel-Cadena E, Herrera-Pavón R, and others (2009) Peces. In:

Editorial responsibility: Gregg Poulakis (Guest Editor), Port Charlotte, Florida, USA
Espinoza-Ávalos J, Islebe GA, Hernández-Arana HA (eds) El sistema ecológico de la bahía de Chetumal/ Corozal: costa occidental del mar Caribe. El Colegio de la Frontera Sur, Chetumal, p 102-114

Seitz JC, Poulakis GR (2002) Recent occurrence of sawfishes (Elasmobranchiomorphi: Pristidae) along the southwest coast of Florida (USA). Fla Sci 65:256-266

Seitz JC, Poulakis GR (2006) Anthropogenic effects on the smalltooth sawfish (Pristis pectinata) in the United States. Mar Pollut Bull 52:1533-1540

Simpfendorfer CA, Kyne PM, Noble TH, Goldsbury J and others (2016) Environmental DNA detects Critically Endangered largetooth sawfish in the wild. Endang Species Res 30:109-116

*Thorson TB (1974) Occurrence of the sawfish, Pristis perotteti, in the Amazon River, with notes on P. pectinatus. Copeia 1974:560-564

Thorson TB (1976) Observations on the reproduction of the sawfish, Pristis perotteti, in Lake Nicaragua, with recommendations for its conservation. In: Thorson, TB (ed) Investigations of the ichthyofauna of Nicaraguan lakes. University of Nebraska-Lincoln, Lincoln, NE, p 641-650

* Thorson TB (1982) The impact of commercial exploitation on sawfish and shark populations in Lake Nicaragua. Fisheries (Bethesda, Md) 7:2-10

* Tregenza NJC (1992) Fifty years of cetacean sightings from the Cornish coast, SW England. Biol Conserv 59:65-70

* Turvey ST, Barrett LA, Yujiang H, Lei Z and others (2010) Rapidly shifting baselines in Yangtze fishing communities and local memory of extinct species. Conserv Biol 24: 778-787

Wiley TR, Simpfendorfer CA (2010) Using public encounter data to direct recovery efforts for the endangered smalltooth sawfish Pristis pectinata. Endang Species Res 12: 179-191

Zarur-Menez A (1962) Algunas consideraciones geobiológicas de la Laguna de Términos. Camp Rev Soc Mex Hist Nat 23:51-70

Submitted: July 25, 2017; Accepted: May 3, 2018

Proofs received from author(s): July 15, 2018 